\title{
THE EARLY WELSH CULT OF ARTHUR: SOME POINTS AT ISSUE
}

\author{
ANDREW BREEZE \\ University of Navarre, Pamplona, Spain
}

\begin{abstract}
A recent discussion of Arthur and Wales prompts a reply, using up-to-date research. It offers these surprising conclusions. Arthur really existed: he is not a myth or a legend, but historical. He will not have been Welsh, but a North Briton, and perhaps a Strathclyder. His battles, fought against other Britons and not the English, can all be located in southern Scotland and the Borders. Camlan, where Arthur fell, can be securely dated to 537 (after the Welsh annals) and situated north of Carlisle on Hadrian's Wall (as proposed in 1935 by O. S. G. Crawford). The battle of Mount Badon in 493 will, however, have nothing to do with Arthur or North Britain. It was a British victory over the English, fought near Swindon and perhaps at the hillfort of Ringsbury overlooking Braydon Forest. Proponents of a Northern Arthur, like Rachel Bromwich (19152010) and Charles Thomas (1928-2016) can thus be vindicated against those rejecting a Northern Arthur, like Professor Kenneth Jackson (1909-91) of Edinburgh.
\end{abstract}

Keywords: Arthur, North Britain, Camlan, Mount Badon, Geoffrey of Monmouth

A recent article by Dr Gerald Morgan provides an interesting survey of Arthurian tradition as seen in Wales (cf. Morgan 2014). Its Welsh focus is defined by the fourteen items in its bibliography. Nine are books published by University of Wales Press; others are an Aberystwyth MPhil thesis of 2009, a paper by the Aberystwyth professor Thomas Jones (1910-72), and a chapter by Dr Morgan, also of Aberystwyth. That leaves two items only from outside Wales, namely books by Wendy Davies and John Morris, both of London.

Celticists in Scotland, Ireland, and beyond will, however, agree that Welsh Arthurian tradition is too important to be left solely to the Welsh. The points on which the present writer disagrees with Dr Morgan are in any case so numerous that they prompt reply. What follows is, therefore, not a complete discussion of Arthurian tradition in Wales, but a commentary on some of Dr Morgan's views. 
It shows that, while some are certainly correct, others are outdated or otherwise unacceptable. We thereby clear away a volume of misinformation which obscures the historical Arthur, who (we maintain) was a warrior in southern Scotland of the 530s, where he campaigned not against the English but other Britons.

1. We start with Dr Morgan on Arthur's power-base: 'various sources claim that his court was at Tintagel or Celli-wig in Cornwall, Caerleon or Chester, Carlisle, Cardiff, or Cardigan' (Morgan 2014: 133).

All these can be rejected. None of them was Arthur's court. The Triads and eleventh-century Mabinogion tale of Culhwch and Olwen put it at Celli-wig, near Penzance in west Cornwall, but their references are vague. The Welsh did not know exactly where Celli-wig was, nor did they care (Sims-Williams 2011: 142). The tradition is no part of history. Although the literary forger Geoffrey of Monmouth (d. 1155) placed Arthur's court at Tintagel (in north Cornwall) and then Caerleon (in south Wales), these are merely his inventions. The earliest historical source for Arthur, the ninth-century Historia Brittonum, mentions no court. Yet its list of battles to be located in North Britain (as argued below) locates the historical Arthur in Scotland, not Cumbria, Wales, or Cornwall. His estate was at an unknown location there, perhaps near Glasgow.

2. After this, a rhetorical flourish. Dr Morgan asks: 'Where did he fight his greatest battle, the battle of Mount Badon? Was it near Badbury in Somerset or Badbury Rings in Dorset, or Mynydd Baedan near Bridgend?' (Morgan 2014: 133).

Dr Morgan does not stay for an answer. We do. Mount Badon was not at Badbury (which is in Wiltshire, not Somerset) or Badbury Rings or Mynydd Baedan. Nor did Arthur fight there. The problem is this. Badon, a British victory over the Saxons, was certainly fought in south Britain. We know this thanks to Gildas, writing in writing in 536 and describing the triumph as occurring at the time of his birth, forty-three years previously (Charles-Edwards 2013: 56, 217). So the conflict belongs to history. Yet Gildas says nothing about Arthur as the victor; Welsh vernacular sources prior to Geoffrey (including triads and native tales) never mention Badon; and nobody has ever found an etymology for Badon, even though its use by Gildas shows it to be Celtic and not English.

There is an exit from this labyrinth. It is provided by the name of Braydon, near Swindon in Wiltshire. Professor Richard Coates (b. 1949) of Bristol relates it to Welsh brad 'treason, betrayal', which must be right (Coates and Breeze 2000: 339). The reference will be to Braydon Forest, ancient and once extensive, the name probably being due to its thieves, who might use it as a base 
to attack travellers on the Roman road to Cirencester. Braydon allows emendation of meaningless 'Badonicus' in Gildas to Bradonicus. Its 'Mount' will be the conspicuous hill looking down on the forest and crowned by the Iron Age hillfort of Ringsbury, near the village of Purton (Pevsner 1975: 376). It was there that Britons in 493 defeated the West Saxon aggressors, probably under the leadership of the Ambrosius Aurelianus mentioned by Gildas. But the battle had nothing to do with Arthur. That is why early Welsh vernacular tradition never mentions it.

3. 'As for his last and fatal battle at Camlan, it is claimed for Hadrian's Wall, for mid-Wales, for Somerset and for Cornwall' (Morgan 2014: 133).

The correct identification is the first. The archaeologist O. G. S. Crawford (1886-1957) suggested in 1935 that the fort of Camboglanna, identified since 1976 as Castlesteads on Hadrian's Wall, was the Camlan of Arthur (Rivet and Smith 1979: 294). Camlan was famous in Welsh tradition as where Arthur met his doom, which is why Historia Brittonum (concerned with victories alone) ignores it. This place near Carlisle nevertheless accords with Northern locations for Arthur's other battles.

4. 'What a puzzle, then, is the figure of Arthur. From Edinburgh to Cornwall, his name has been scattered across the British landscape, nowhere more so than in Wales' (Morgan 2014: 133).

If the reasoning in the present paper is coherent, Arthur will cease to be a puzzle. He will become fact.

5. 'The names are not necessarily ancient, but their frequency and variety is [sic] significant.' (Morgan 2014: 133).

The significance here is the association of Arthur (whom we take as a Northerner) with sites in Wales unknown to him. It has parallels. The same thing occurred for Taliesin, Llywarch the Old, Tristan, and Urien Rheged, all of them Northerners, as Rachel Bromwich observed in her edition of the Triads (cited by Dr Morgan), in discussing Llywarch. As regards Arthur, the process had (as Dr Morgan states) begun in Wales by 800, with rocks on the Upper Wye associated with his hound, and a mound near Hereford taken as the grave of his son. But these are folklore references. As a basis for locating Arthur in Wales, they are worthless. In this they differ from the battlefields also listed by Historia Brittonum. With one exception, they can be located in Scotland or northern England, and so belong to authentic tradition. Their very obscurity proves this. A mere forger would not chose unfamiliar places but famous ones, as Geoffrey of Monmouth did with Winchester, Lincoln, or York. The point is proved by Badon, the only one of the nine battlefields that (owing to Gildas) the 
early Welsh knew of. Its presence in the Historia Brittonum list shows contamination of original material as early as the ninth century. It contrasts with texts in Welsh, which never mention Badon until Geoffrey of Monmouth in the twelfth century began to infect vernacular tradition with his pseudo-historical inventions.

6. 'For more than a hundred years serious scholars have pored over medieval documents in Latin, Welsh, French, and English, searching for the historical Arthur' (Morgan 2014: 133-134).

If scholars seek evidence for the historical Arthur in medieval English or French, they waste their time. The real testimony is in Welsh and Latin alone, in documents from Wales earlier than Geoffrey of Monmouth. They are the oldest and most authentic evidence, predating his blatant literary fabrications. The sole exception here is material in Latin and Irish for Arthur as a royal name in Scotland and Ireland after about 560.

7. 'Archaeologists have used the promise of the discovery of Arthur's court (most recently in Chester) to raise interest and funds' (Morgan 2014: 134).

If archaeologists expect to find Arthur's court at Chester, they deceive themselves. They also waste time and money. The most notorious instance of this concerns excavations at South Cadbury, Somerset (Alcock 1972). They were extensively reported in the British media, avid for Arthurian news stories. After sharp criticism by Charles Thomas (1928-2016) and David Dumville (b. 1949), however, their director admitted defeat. 'It is necessary to stress at this point that, within the scholarly framework of the 1950s and 1960s, the Arthur/Camelot attribution seemed a reasonable inference. The sustained minimalist criticism of the historicity of Arthur was only launched publicly in the late 1970s' (Alcock 1995: 6). There are (of course) excellent reasons for excavating a hillfort in Somerset or Roman town in Cheshire. But if archaeologists assert that we shall find Arthurian remains there, they should not be believed.

8. 'Yet these well-meaning, enthusiastic, and highly intelligent people cannot even agree whether Arthur was a real man of flesh and blood or not' (Morgan 2014: 134).

The phrasing is redundant. Arthur could not have been a real man without having flesh and blood. That aside, we argue not only that Arthur had both, but used them to shed the blood of others. Some may feel that, while these investigators are undoubtedly well-meaning and enthusiastic, if they really possessed intelligence (high or not), they would not treat Historia Brittonum's confused and corrupt text with simple-minded literalism. 
9. 'Did he lead bands of mounted warriors against the colonizing English in mid-southern England in the early sixth century $\mathrm{AD}$, as a major historian believed?' (Morgan 2014: 134).

The answer is no. There are two myths here: that Arthur was a cavalry commander, and that he fought the English. Both can be laid at the door of R. G. Collingwood (1889-1943), Oxford archaeologist and philosopher. On the first we quote Kenneth Jackson (1909-91) of Edinburgh. Commenting on the 'dogma among some writers that the British peoples in the Dark Ages had a great military organization like a sort of Horse Guards or Dragoons', he observed that 'there is not the slightest real evidence that Arthur, if he ever existed, had anything whatever to do with cavalry'. After giving reasons why, he concluded: 'But no doubt we shall see characters in Welsh Dark Age tradition claimed as "Roman cavalry officers" for a long time to come' (Jackson 1969: 85, 86). That was in 1969. In 2014, we find Dr Morgan still giving unwarranted credence to Arthur as cavalry commander. Jackson's 'for a long time to come' was prophetic indeed. On Arthur as scourge of the English, the battles ascribed to him disprove that. When Arthur lived, there were no English in southern Scotland. His campaigns were against other Britons.

10. 'The opinion of most leading scholars is that, if Arthur was a historical person, then we know nothing about him, not a single hard fact about his life' (Morgan 2014: 134).

It is hard to see how a person can be both 'historical' and 'unknown'. To be historical, a person must have authentic documentation. What Dr Morgan means is 'if Arthur ever existed, then we know nothing about him'. This article has been written to show that we know much about Arthur. He had a Latin name (Artorius), not a native British one; fought in North Britain; and was of exalted rank, but not royal, although princes after his time were called after him. We can be confident that he was a Christian; spoke Latin and British; was a brave warrior, successful until his last battle on Hadrian's Wall; and probably came from Strathclyde, from which he attacked Gododdin and Rheged territory, also apparently defending Strathclyde against their armies.

11. 'If Arthur was a historical figure, then he must belong in the first half of the sixth century, at the time when English settlers were slowly spreading across the land' (Morgan 2014: 134).

Arthur certainly lived in the earlier sixth century. But English settlers are here irrelevant. He neither fought them nor impeded their progress. 
12. 'Among all the later defeats [of the Welsh] it would clearly be valuable if a figure could be seized upon who had been a victor, at least for a while, against the English' (Morgan 2014: 135).

Arthur did not fight the English, as stated. Yet the chapter on his battles in Historia Brittonum puts him in the context of wars against the Anglo-Saxons of Kent, leading to incalculable confusion amongst historians, who have vainly tried to locate his engagements in the South, their one success being with Mount Badon (which, however, Arthur did not fight). Ninth-century Welsh historians, having little interest in North British wars of the sixth century, naturally assumed that Arthur campaigned against the English, the eternal foe. Their misinterpretation has misled scholars ever since.

13. 'Another [bard] compared the Powys prince Cynddylan and his brothers, writing many years after their deaths in the seventh century, as being "like whelps of mighty Arthur"' (Morgan 2014: 135-136).

The reference to Arthur in the poem cited is not original, but due to emendation by Sir Ifor Williams (1881-1965) of Bangor. A later editor interprets artir wras in the text as 'strong-handed', and so 'strong-handed whelps' (Rowland 1990: 177, 186). She is surely right. The allusion to Arthur is spurious.

14. On Welsh annals we read this: 'In the year 516 occurred "the battle of Badon, in which Arthur carried the image of Christ on his shoulders for three days and three nights, and the Britons were victorious". In the year 537 "the battle of Camlan, in which Arthur and Medraut fell"” (Morgan 2014: 136).

Dr Morgan takes these allusions to Arthur as perhaps late interpolations. We agree with him, in part. The comment on Arthur and a sacred symbol at Badon is clearly legendary; it breaks the syntax of the entry; and early vernacular tradition knows nothing of Arthur at Badon. It must be rejected. Camlan is another case. Here the statement on Arthur is bald and factual; it does not bear the trappings of saga, even if legends of Medrawd's treachery developed later; early Welsh tradition says much on Arthur at Camlan; and, as noted, Crawford in 1935 located Camlan in the North, on Hadrian's Wall. The later entry can be accepted as historical. Its date provides a further reason for ruling out Arthur's presence at Badon, a battle of battle of 493 (not 516). It is unlikely that Arthur campaigned in both the 490s and in 537. Camlan knew him, Badon did not.

15. Historia Brittonum lists Arthur's battles, at nine sites. Dr Morgan give these forms: River Glein; River Dubglas; River Bassas; Caledonian Forest: Guinnon Fort: City of the Legion: River Tribruit: Hill of Agned; Badon Hill. He comments: 'Speculation on these place-names, none of which can be identified with certainty, is endless but useless' (Williams 2014: 137). 
With the final words we heartily agree. Speculation is emphatically 'endless but useless'. But informed philological analysis is another matter, allowing us to identify each one of these locations. Badon Hill is dealt with above as Ringsbury Hill, above Braydon Forest, Wiltshire. Others may be discovered on the basis of discussion by William Watson (1865-1948) of Edinburgh. Before that we make some points. First, Historia Brittonum puts the River Dubglas in the region of Linnuis, and refers to the stronghold of Guinnion, not 'Guinnon' (Higham 2002: 144). Second, Glein is accepted as the River Glen in north Northumberland (Watts 2004: 252). Third, on Dubglas, the Linnuis of the text has often been taken as Lindsey or north Lincolnshire. This lacks sense. There is no River Douglas in Lincolnshire. We thus emend to Cluduis '(people of) Strathclyde', a form attested by the tenth-century poem Armes Prydein 'The Prophecy of Britain' in the Book of Taliesin (Lloyd-Jones 1931-1963: 149).

Dubglas will therefore be Douglas Water, near Lanark, Strathclyde. 'Bassas' is meaningless as it stands; emend to Tarras, the name of rivers in Eskdale (near the English border) and formerly near Carstairs, Strathclyde. The Caledonian Forest (as Celyddon) was also located by the Welsh in Strathclyde. It was where Merlin hid in his madness, and so can be placed in the wild country around Beattock Summit, between Carstairs and Lockerbie. The fort of Guinnion will not (as this writer previously thought) have been at Kirkgunzeon, near Dumfries in south-west Scotland; it was surely (as proposed by Tim Clarkson of Manchester) Carwinning, a minor defence three kilometres west-south-west of Kilbirnie, in south-west Scotland. 'City of the Legion' is surely an error for KARIG LION 'Rock of the Legions', near Kinneil, West Lothian, at the end of the Antonine Wall. Tribruit, the name not of a river but a beach by a river (in litore fluminis), is Dreva, on the Tweed west of Pebbles, where the $v$ rules out an English etymology. Agned is a corruption of Old Welsh agheu 'death'; it will be Pennango 'death hill', an obsolete toponym located near Hawick, Borders. Evidence on all these forms is provided by Watson in the order Celyddon, Guinnion, Agned, Tribruit, City of the Legion, Bassas, Dubglas (Watson 1926: 71, 165, 354, 363, 383-4, 386-7, 457-8).

Once Badon is excluded from the Arthurian tally, and Camlan/Castlesteads in Cumbria added to it, we may plot the toponyms on the map. A significant pattern emerges. Not only are all nine places in southern Scotland or the extreme north of England, but none is in the heart of Strathclyde, while four are in the territory of the Gododdin (south-east Scotland, with its capital at Edinburgh) and either two or three in Rheged (around the Solway Firth and including modern Cumbria). The implication is evident. Arthur will have been a Strathclyder engaged in wars against Rheged and the Gododdin. The two or three place-names remaining, for conflicts on Douglas Water and in the Caledonian Forest, and that on the 'Bassas'/Tarras (if the river near Carstairs 
and not the one further south, in Eskdale), are best interpreted as defensive. Arthur will there have repelled attacks on Strathclyde by other North Britons. Simple analysis of evidence in print since 1926 hence reveals Arthur, not merely as a Briton of the North, but a Strathclyder. Small wonder that his name was given in the later sixth century to a Gaelic prince of the Argyll region, a kinsman of Strathclyde's ruling dynasty (Bannerman 1974: 90-91). Small wonder too that we hear nothing of Arthur in the poetry of Taliesin, court poet to Rheged, and almost nothing in that of Aneirin, bard to the Gododdin. Praise of an enemy was no task of these poets.

16. After Arthurian battles, two early Arthurian poems, which prompt this comment. 'Has a historical figure of the sixth century been enveloped in legend and the supernatural, as to an extent were Charlemagne and Owain Glyn Dŵr? Or has a giant-fighting hero with his legendary companions been credited with factual existence for the sake of Welsh morale?' (Morgan 2014: 139).

There are three points here. Of the two poems, 'What Man is the Porter?' (in the thirteenth-century Black Book of Carmarthen) mentions fighting and shattered shields at Tryfruid in the context of Eidyn or Edinburgh. It is independent confirmation of the place's northern location. The other and more fantastic one, 'Spoils of Annwn', telling of Arthur's raid on the Other World, now has an up-to-date edition and translation (Haycock 2007: 433-451). Finally, we can answer Dr Morgan's questions. A historical figure of the sixth century has indeed been 'enveloped in legend and the supernatural', like Charlemagne and Owen Glendower. Arthurian fire produced Arthurian smoke.

That Arthur can be identified as a Northern hero, active in the 530s, and fighting at localities all now to be found on the map, is both an end and a beginning. It means that we can dismiss the comment by Professor Halsall of York on the nine places of conflict that THE LOCATIONS OF ALL OF THESE BATTLES ARE UNKNOWN AND UNKNOWABLE (the capitals are his) (Halsall 2013: 67). Further, writers on the Anglo-Saxon settlements should exclude Arthur from their narratives. He had no connection with the British victory in 493 at 'Badon' or Braydon, which was achieved by another, probably the Ambrosius Aurelianus lauded by Gildas. Literary scholars, on the other hand, may now see Arthur as a Northern leader, in his culture partly Latin and partly British, whose campaigns in southern Scotland made him a pan-British hero, the legends of him thereafter undergoing astonishing transformation by medieval narrators. Through them, an obscure British warrior of the sixth century obtained world-wide fame (Breeze 2015). This being a Polish journal, we end with a comment on Poland, where Arthur was known by the late twelfth century. Wincenty Kadłubek (1150?-1223), Bishop of Kraków in 1208-18, took Geoffrey of Monmouth's Historia Regum Britanniae as a model for his 
Chronica Polonorum (which goes up to the year 1202) (Michałowska 1995: 137). Seven centuries after the original Arthur flourished on the banks of the Clyde, he was known and admired on the banks of the Vistula: a British hero famous amongst Slavs.

\section{REFERENCES}

Alcock, Leslie. 1972. 'By South Cadbury is that Camelot...': The Excavation of Cadbury Castle, 1966-1970. London: Thames and Hudson.

Alcock, Leslie. 1995. Cadbury Castle, Somerset. Cardiff: University of Wales Press.

Bannerman, John. 1974. Studies in the History of Dalriada. Edinburgh: Scottish Academic Press.

Breeze, Andrew. 2015. 'The Historical Arthur and Sixth-Century Scotland'. Northern History 52: $158-181$.

Charles-Edwards, T. M. 2013. Wales and the Britons 350-1064. Oxford: Oxford University Press.

Coates, Richard and Andrew Breeze. 2000. Celtic Voices, English Places. Stamford: Shaun Tyas.

Halsall, Guy. 2013. Worlds of Arthur. Oxford: Oxford University Press.

Haycock, Marged. 2007. Legendary Poems from the Book of Taliesin. Aberystwyth: CMCS.

Higham, N. J. 2002. King Arthur. London: Routledge.

Jackson, K. H. 1969. The Gododdin: The Oldest Scottish Poem. Edinburgh: Edinburgh University Press.

Lloyd-Jones, John. 1931-1963. Geirfa Barddoniaeth Gynnar Gymraeg. Caerdydd: Gwasg Prifysgol Cymru.

Michałowska, Teresa. 1995. Średniowiecze. Warszawa: Wydawnictwo Naukowe PWN.

Morgan, Gerald. 2014. 'The Early Welsh Cult of Arthur'. Res Celticae 1: 133-145.

Pevsner, Nikolaus. 1975. The Buildings of England: Wiltshire. 2nd edn. Harmondsworth: Penguin.

Rivet, A. L. F. and Colin Smith. 1979. The Place-Names of Roman Britain. Princeton: Princeton University Press.

Rowland, Jenny. 1990. Early Welsh Saga Poetry. Cambridge: D. S. Brewer.

Sims-Williams, Patrick. 2011. Irish Influence on Medieval Welsh Literature. Oxford: Oxford University Press.

Watts, Victor. 2004. The Cambridge Dictionary of English Place-Names. Cambridge: Cambridge University Press. 